Fatma Yonsel

Gülçin Vural

http://dx.doi.org/10.21278/brod68305

ISSN 0007-215X

eISSN 1845-5859

\title{
KPI (KEY PERFORMANCE INDICATORS) APPLICATION ON BALLAST WATER TREATMENT SYSTEM SELECTION
}

UDC 629.5.062.2

Original scientific paper

\begin{abstract}
Summary
Every day, more than 7,000 different marine species are transferred to different ecosystems via ballast water in ships. The introduction of invasive species can cause problems for native species. After realizing the serious potential problems associated with the transport of organisms in ballast water, national and international regulations were developed. In 2004, the International Maritime Organization introduced the International Convention for the Control and Management of Ships' Ballast Water and Sediments. With these regulations, the problems caused by ballast water have attracted attention and many companies have started to research and develop technologies for the management of ballast water. Today, there are hundreds of different systems for ballast-water treatment, and the selection of the most suitable system for a specific vessel is an increasingly important issue as the Convention nears enforcement on September 8, 2017. The goal of this study is to demonstrate that the application of key performance indicators (KPIs) to the selection of a ballast-water treatment system (BWTS) leads to a very useful tool with which shipyards can compare BWTSs. This allows them to make better choices and to designate the most suitable system for each of their ships. In this study, we examine two types of vessel from a shipyard in Istanbul, Turkey. They have different ballast-water capacities and equipment, and the most suitable system for each is selected by using the KPI method.
\end{abstract}

Key words: $\quad$ ballast water; ballast-water treatment systems; KPI; key performance indicators;

\section{Introduction}

In general, ballast refers to material that is used either to provide stability to a vessel or improve the efficiency of its propulsion system by adjusting the position of its propeller in the water. In the 1800 s, solid materials such as sand, detritus, and iron were usually loaded onboard to provide ballast. After use, these materials were discharged into the sea for use by other ships. However, this technique was both time-consuming and ineffective, and by the end of the $1800 \mathrm{~s}$ technological progress had led to seawater being used as ballast instead [1]. Nowadays, ballast water can account for 30\%-35\% of the deadweight of a vessel [2]. However, seawater received into ballast tanks can be a medium in which to transport fish eggs, larvae, bacteria, and phytoplankton to different ecosystems upon discharge. These organisms, which are called nonnative species, can be invasive in the new ecosystem [3]. 
Human-induced factors can greatly disturb the natural balance of a marine ecosystem. The introduction of invasive marine species into new environments via ship ballast water has been stated as one of the four greatest threats to marine ecosystems. Problems due to invasive species can be analyzed in relation to their impacts on three main areas: ecology, economy, and health. These species may hunt the local species and cause their extinction, leading to changes in the natural ecosystem. Changes in biodiversity and extinction of native species may cause irreversible damage.

The problems caused by invasive species are not limited to ecological damage; they may also pose economic problems. For example, an invasive species may feed on the fish that naturally inhabit that region, or the eating habits of the invasive and local species might be similar, leading to competition over prey. Such situations end up reducing the local fish population, thereby negatively affecting the local fishing activities. Moreover, invasive species such as algae can damage fish farms, and some invasive species attach themselves to surfaces, thereby damaging coastal and port buildings and facilities. Furthermore, the reproduction of invasive species such as algae on beaches has negative economic effects regarding tourism (around $€ 2.2$ billion per year in Europe) [3]. Another significant problem caused by invasive species is their effect on human health. Ballast water may contain toxic organisms and pathogens, some of which can be absorbed by mussels and oysters; eating such infected seafood can be dangerous.

The best-known examples of the environmental effects of invasive species have been recorded in the Great Lakes of the United States (US). This area has been damaged by more than 180 invasive species during recent years. Zebra mussels, sea lamprey, and alewife, among others, were introduced to lakes and spread, competing with native species and damaging the food chain. Such invasions have also affected fisheries, factories, and coastal areas. The zebra mussel has spread to more than $40 \%$ of US waters and cost more than US\$1 billion over 19892000 [4]. Studies conducted by the US Fish and Wildlife Service have shown that this damage escalated to roughly US\$5 billion for 2000-2010 [5].

After realizing the serious problems that could be caused by organisms carried in ballast water, a number of national and international regulations were introduced. Although various regional and local regulations are in place around the world, the two most significant and widely recognized organizations to have imposed regulations on ballast-water treatment are the International Maritime Organization (IMO) and the United States Coast Guard (USCG). The IMO's International Convention for the Control and Management of Ships' Ballast Water and Sediments, 2004 (hereinafter referred to as "the Convention") will enter into force on September 8, 2017. The Convention seeks to prevent the spread of harmful aquatic organisms from one region to another by establishing standards and procedures for the management and control of ships' ballast water and sediments. As of January 11, 2017, there were 54 Contracting States to the Convention, representing $53.30 \%$ of the world's global tonnage [6].

After the Convention enters into force, all ships greater than 400 Gross Tonnage should comply with the Ballast Water Performance Standards with a schedule based on their keellaying date. Hence, each ship in that category will be equipped with an IMO-type-approved ballast-water treatment system (BWTS), costing the global maritime industry an estimated US $\$ 100$ billion. The US is not a State Party to the Convention; it has its own requirements instead. In particular, USCG regulations require most ships operating and discharging ballast water in US waters to have a ballast-water management (BWM) system. This must be approved by the USCG, meet the USCG's testing standards, and be installed at the first scheduled dry docking after January 1, 2016 [7]. 
There are more than 100 BWTSs available on the market. However, only 69 systems have IMO type-approval [8]. The process of approving systems and installing them is already underway. The technologies that are either currently available or being developed can generally be grouped in three broad categories based on their primary mechanism for rendering the organism inactive: mechanical, physical, or chemical [9].

The task of comparing BWTSs and selecting the best one has fallen to today's researchers. It is very important to identify and standardize the BWTSs used for the different segments, as well as to find the best solution for all ships in a fleet. Ultimately, we seek to help the shipbuilding and maritime sectors of our country adapt to this process.

Many studies have investigated the problem of comparing and selecting a BWTS. Perakeis and Yang [10] considered it impossible to determine the overall cost and benefit of each BWTS; instead, they compared different BWTSs based on their operating and capital costs. Rigby [11] argued that the influence and interaction of factors such as seasonality and voyage parameters need to be taken into account in identifying the best BWTS. Parsons [12] reported that even the selection of the best primary treatment for ballast water is a discrete multi-criterion optimization and a type of decision-making problem. Parsons used the analytical hierarchy process (AHP) to supply the decision options and arrange the factors in a hierarchy of relationships; this was then used to select the primary treatment device for a BWTS. In 2005, Gomes [13] used the THOR software for its intended purpose of supporting and guiding decision makers in evaluating and selecting the best BWTS. The THOR method was able to compare three BWM methods, but the model's comparison was based on only three BWM alternatives. In 2008, Mamlook et al. investigated the problem of selecting the optimum BWTS, using fuzzy sets to compare eight BWTSs according to cost/benefit ratio [14]. Berntzen developed a BWTS decision-support system that considered both technical and economic aspects [15]. Compatibility analysis (known as technical evaluation) and key performance indicator (KPI) analysis (known as KPI evaluation) allowed some systems to be excluded from the running early on in the selection process. The model identified six to eight systems that were applicable to the ships in question. This list was reduced by applying ship-specific constraints and certain additional information about each system under evaluation. In 2015, Al Hababi developed an AHP model as a tool for selecting a BWTS; which considers both the ship and the ballast water system's parameters/criteria. Specifically, ship compatibility was considered for a very large crude-oil carrier on a specific trade route [16].

The main goal of the present study is to use a decision-support tool that can be applied to a wide variety of treatment systems. Many studies on this subject were examined, and we concluded that the KPI method is better understood and more applicable than the other options, given that it is used in many shipyards for many other decision-making purposes (e.g., budget performance, dry-dock planning performance, cargo-related incidents, operational deficiencies, passenger injury ratio, port state control detention, vessel availability, and vetting deficiencies) [17]. Besides that, KPIs can be used to quantify a company's ability to adhere to applicable rules and regulations related to the management of ballast water. This is done basically by counting the number of times that prevailing regulations regarding management of ballast water have been violated and recorded by an external party [18].

In the present study, we discuss in detail the use of the KPI method to select a BWTS for a fishing vessel and another for a dry bulk carrier. The shipyard in Istanbul that built both ships is already familiar with the KPI approach. The vendors of the BWTSs and the companies that purchased the vessels are kept confidential. 


\section{IMO regulations: ballast-water exchange and performance standards}

Invasive aquatic species present a major threat to marine ecosystems, and shipping has been identified as a major pathway for introducing species to new environments. The problem has increased as trade and traffic volume have expanded over the past few decades. In particular, the introduction of steel hulls allowed vessels to use water instead of solid materials as ballast. The BWM Convention ("the Convention") was adopted in 2004 and comes into force in September 2017. This aims to prevent the spread of harmful aquatic organisms from one region to another by establishing standards and procedures for the management and control of ship ballast water and sediments. Under the Convention, all ships engaged in international traffic are required to manage their ballast water and sediments to a certain standard according to a shipspecific BWM plan. All ships will also have to carry a ballast-water record book and an international BWM certificate. The BWM standards will be phased in over a period of time. As an intermediate solution, ships should change their ballast-water mid-ocean. A number of guidelines have been developed to facilitate the implementation of the Convention. The Convention is divided into Articles, together with an Annex that includes technical standards and requirements in the Regulations for the control and management of ship ballast water and sediments [19].

Regulation D-1 requires that ships performing ballast-water exchange shall do so with an efficiency of $95 \%$ volumetric exchange of ballast water. For ships exchanging ballast water by the pumping-through method, pumping through three times the volume of each ballast water tank shall be considered to meet the standard described. Pumping through less than three times the volume may be accepted provided the ship can demonstrate that at least $95 \%$ volumetric exchange is met [9].

Regulation D-2 requires that ships conducting BWM shall discharge fewer than 10 viable organisms per cubic meter that are greater than or equal to 50 micrometers in minimum dimension, and fewer than 10 viable organisms per milliliter that are less than 50 micrometers in minimum dimension and greater than or equal to 10 micrometers in minimum dimension; and discharge of the indicator microbes shall not exceed the specified concentrations (Table 1) [9]. All BWTSs must be approved by a Flag state before being sold to a client. It is worth noting that a BWTS that uses active substances has to go undergo a more thorough certification process and obtain Basic and Final approval by the IMO [20]. All BWTSs are tested on land to ensure that regulation D-2 is met over 10 cycles as a minimum.

Table 1 IMO Ballast-Water Regulation D-2 [9]

\begin{tabular}{|c|c|}
\hline Microorganism & IMO Regulation \\
\hline Organisms $\geq 50 \mu \mathrm{m}$ & $\begin{array}{l}<10 \text { viable organisms per } \mathrm{m}^{3} \text { of ballast } \\
\text { water }\end{array}$ \\
\hline $50 \mu \mathrm{m}>$ Organisms $\geq 10 \mu \mathrm{m}$ & $\begin{array}{c}<10 \text { viable organisms per ml of ballast } \\
\text { water }\end{array}$ \\
\hline Toxicogenic Vibrio cholera & $\begin{array}{l}<1 \text { colony forming unit (CFU) per } 100 \\
\mathrm{ml}\end{array}$ \\
\hline Escherichia coli & $<250 \mathrm{CFU}$ per $100 \mathrm{ml}$ \\
\hline Intestinal Enterococci & $<100 \mathrm{CFU}$ per $100 \mathrm{ml}$ \\
\hline
\end{tabular}




\section{United States Coast Guard (USCG) regulations}

In addition to the IMO BWM Convention requirements, the USCG has established both regulations and guidelines in response to the ecological and economic impacts of zebra mussel invasion into the North American Great Lakes. On the March 23, 2012, the USCG issued its final regulations on BWM entitled "Standards for Living Organisms in Ship's Ballast-Water Discharged in USA Waters," aimed at preventing the introduction and spread of aquatic nuisance species into USA waters through the ballast water of ships. The final rule was issued in June 2012 and applies to all ships equipped with ballast tanks. The USCG added a provision to allow for a temporary acceptance of a foreign administration's approval of a BWTS if it can be shown that the foreign approved BWTS is at least as effective as ballast-water exchange. This temporary acceptance will be granted for five years from the date that the ship on which the BWTS is installed is required to comply with USCG regulations. The USCG's discharge standard is the same as the IMO's performance standard. In 2009, the USCG proposed a phasetwo standard that is more stringent than the IMO-D2 standard. Some states (e.g., California and New York) have specific BWM requirements or standards that have more stringent requirements [20].

\section{Materials and Methods}

Key performance indicators are expressions of performance within a specific area. A KPI can be expressed in one of two ways: as a KPI value that is a mathematical combination of relevant performance-indicator values, or as a KPI rating that is an expression of the KPI value on a scale between 0 and 100, where the highest rating (100) corresponds to the highest or most excellent performance [18]. Methods based on KPIs allow assessment of progress made in accordance with measurable goals. In order to obtain successful results, the steps and measurement criteria should be selected properly.

There are many companies that manufacture BWTSs, and as has already been mentioned, there have been many studies into the problem of comparing and selecting a BWTS. The KPI approach is a practical method for recommending a suitable BWTS for a particular ship or fleet, and is a known decision or performance-measurement tool in many areas of the shipping industry. The model was created in Microsoft Excel (hereinafter "Excel") and evaluates parameters from the ship, compares it to the data collected from different vendors, and finally advises whether the system is applicable for each ship.

In this study, we discuss in detail the selection of a BWTS for a fishing vessel and another for a dry bulk carrier by using a KPI-based decision tool. Excel is available to most end users. In our case, these are the employees of the shipyard that built the fishing vessel and the dry bulk carrier, the technical data of which are given in Table 2 . 
Table 2 Technical details of fishing vessel and dry bulk carrier [21]

\begin{tabular}{|c|c|c|}
\hline Technical data & Fishing vessel & Dry bulk carrier \\
\hline $\begin{array}{l}\text { LOA } \\
\text { (Length over all) }\end{array}$ & $72.4 \mathrm{~m}$ & $68 \mathrm{~m}$ \\
\hline B (Width) & $15.2 \mathrm{~m}$ & $12.5 \mathrm{~m}$ \\
\hline $\mathrm{D}$ (Depth) & $9.20 \mathrm{~m}$ & $6.8 \mathrm{~m}$ \\
\hline $\mathrm{T}$ (Draught) & $7.8 \mathrm{~m}$ & $5.7 \mathrm{~m}$ \\
\hline Gross tonnage & 2,720 tonnes & 1,550 tonnes \\
\hline Class & $\begin{array}{l}\text { DnV (Norske Veritas) } \\
+1 \mathrm{~A} 1 \text {, Fishing Vessel, } \\
\text { Ice C, E0 }\end{array}$ & $\begin{array}{l}\text { BV (Bureau Veritas) } \\
\text { I+HULL+MACH, } \\
\text { General Cargo, Heavy Load [10 } \\
\text { kN/m²], Occasional Dry Bulk } \\
\text { Cargo, Navigation }\end{array}$ \\
\hline Ballast-water capacity & $350 \mathrm{~m}^{3}$ & $870 \mathrm{~m}^{3}$ \\
\hline $\begin{array}{l}\text { Ballast-water pump } \\
\text { capacity }\end{array}$ & $1 \times 50 \mathrm{~m}^{3} / \mathrm{h}$ at $2.5 \mathrm{bar}$ & $2 \times 125 \mathrm{~m}^{3} / \mathrm{h}$ at $2.5 \mathrm{bar}$ \\
\hline
\end{tabular}

4.1 Key data factors for fishing vessel and dry bulk carrier

To perform KPI analysis, it is necessary firstly to specify important criteria that are known as the "key data" (key factors). After that, the limitations of these criteria have to be identified for each key data. In Table 3, the key factors and their importance levels are given both for the fishing vessel and the dry bulk carrier. Each key factor has its own level of importance, and these values were set arbitrarily during the analysis [21].

Table 3 KPI key factors

\begin{tabular}{|c|c|}
\hline KPI & Importance \\
\hline Pressure loss & $20 \%$ \\
\hline $\begin{array}{c}\text { Footprint } \\
\text { (area of BWTS) }\end{array}$ & $15 \%$ \\
\hline Investment cost & $50 \%$ \\
\hline Operation cost & $15 \%$ \\
\hline
\end{tabular}

In addition to the data given in Table 3, other technical and cost data have to be considered to conduct an accurate comparison. Installation and operation criteria are given in Table 4. 
Table 4 Installation and operation criteria

\begin{tabular}{|c|c|}
\hline Item & Importance \\
\hline Use of chemicals & Critical \\
\hline USCG standards & Critical \\
\hline Treatment time & Critical \\
\hline Installation cost & Secondary \\
\hline Total investment cost & Secondary \\
\hline Fuel cost & Secondary \\
\hline Maintenance cost & Secondary \\
\hline
\end{tabular}

At this stage, the key factors are compared with data obtained from each system, and the model created in Excel generates a $(1 \times 11)$ binary matrix in which 1 means "OK" and 0 means "not OK." If all the key data, the critical operation criteria, and at least two of the secondary operation criteria are OK, the system will be evaluated as "Applicable." If all the key data and the critical operation criteria are OK, but fewer than two of the secondary operation criteria are OK, the system will be evaluated as "Partly Applicable." Finally, if any of the key data is not OK, the model will reject the system and evaluate it as "Not Applicable."

\subsection{KPI evaluation of fishing vessel and dry bulk carrier}

To compare the key factors, the available data are graded on a scale of $1-6$, where 1 is the best grade for each factor and 6 is the worst. The evaluation is done on the basis of the best value in each category. The equations given below are from Berntzen's study [15]:

$$
\begin{aligned}
& C_{i}=\frac{n_{i}}{n_{\min }} \\
& C_{G \max }=G \times \frac{C_{\max }-1}{6}+1 .
\end{aligned}
$$

In Eq. (1), $n_{i}$ is the actual value of the system and $n_{\min }$ is the best value in that category. With this equation, the coefficients for each key factor are obtained. In Eq.(2), $G$ is the grade from 1 to 6 , and $c_{\max }$ is the maximum coefficient in the calculated category. With these equations, the maximum grades for each system are calculated [21]. 


\section{Results of case study with fishing vessel and dry bulk carrier}

5.1 KPI-based selection of BWTS: fishing vessel

For each vessel, we consider three different BWTSs from different vendors. The technical specifications of those considered for the fishing vessel are given in Table 5. The vendors of BWTSs have been kept confidential.

Table 5 Technical specifications of BWTSs considered for fishing vessel

\begin{tabular}{|c|c|c|c|c|}
\hline \multirow{2}{*}{\multicolumn{2}{|c|}{$\begin{array}{c}\text { Method used to treat } \\
\text { ballast water }\end{array}$}} & \multirow{2}{*}{$\begin{array}{c}\text { System 1 } \\
\text { Filtration + UV }\end{array}$} & \multirow{2}{*}{$\begin{array}{c}\text { System } 2 \\
\text { Pre-filtration + } \\
\text { Filtration + UV }\end{array}$} & \multirow{2}{*}{$\begin{array}{c}\text { System } 3 \\
\text { Filtration + UV }\end{array}$} \\
\hline & & & & \\
\hline \multirow{2}{*}{ Treatment } & Uptake & Filtration + UV & $\begin{array}{l}\text { Pre-filtration + } \\
\text { Filtration + UV }\end{array}$ & Filtration + UV \\
\hline & Discharge & UV & UV & UV \\
\hline \multicolumn{2}{|c|}{ Filter } & 55 microns & $\begin{array}{l}200 \text { microns pre- } \\
\text { filter } \\
50 \text { microns filter }\end{array}$ & 40 microns \\
\hline \multicolumn{2}{|c|}{ Pressure drop } & 0.7 bar & 0.9 bar & 0.3 \\
\hline \multicolumn{2}{|c|}{ UV unit capacity } & $85 \mathrm{~m}^{3} / \mathrm{h}$ & $50 \mathrm{~m}^{3} / \mathrm{h}$ & $50 \mathrm{~m}^{3} / \mathrm{h}$ \\
\hline \multicolumn{2}{|c|}{ Power Usage } & $10-15 \mathrm{~kW}$ & $16 \mathrm{~kW}$ & $19 \mathrm{~kW}$ \\
\hline
\end{tabular}

The input criteria given in Table 6 are used in the Excel model. The values for each system are stated in Table 7.

The values given in Table 6 are compared with the values in Table 7, and the model generates a $(1 \times 11)$ binary matrix in which 1 means "OK" (i.e., the criterion is met) and 0 means "not OK" (i.e., the criterion is not met). Table 8 gives the $(1 \times 11)$ matrix that was generated in Excel [21]. 
Table 6 KPI analysis input data

\begin{tabular}{|c|c|}
\hline KPI & Criterion \\
\hline Pressure drop & $1 \mathrm{bar}$ \\
\hline Footprint (area of BWTS) & $4 \mathrm{~m}^{2}$ \\
\hline Equipment price & $\$ 200,000$ \\
\hline Annual operation cost & $\$ 2,500$ \\
\hline Use of chemicals & No \\
\hline USCG standards & No \\
\hline Treatment time & Uptake \\
\hline Installation cost & $5 \%$ of equipment price \\
\hline Total investment cost & $\$ 210,000$ \\
\hline Fuel cost & $\$ 500$ \\
\hline Maintenance cost & $\$ 2,000$ \\
\hline
\end{tabular}

Table 7 KPI analysis system data

\begin{tabular}{|c|c|c|c|}
\hline & System 1 & System 2 & System 3 \\
\hline Pressure drop & $0.7 \mathrm{bar}$ & $0.9 \mathrm{bar}$ & $0.3 \mathrm{bar}$ \\
\hline Footprint (area of BWTS) & $2.17 \mathrm{~m}^{2}$ & $5.62 \mathrm{~m}^{2}$ & $3.57 \mathrm{~m}^{2}$ \\
\hline Equipment price & $\$ 185,000$ & $\$ 203,000$ & $\$ 200,000$ \\
\hline Annual operation cost & $\$ 1,240$ & $\$ 14,650$ & $\$ 2,100$ \\
\hline Use of chemicals & No & No & No \\
\hline USCG standards & No & No & No \\
\hline Treatment time & Uptake & Uptake & Uptake \\
\hline Installation cost & $\$ 7,100$ & $\$ 11,150$ & $\$ 6,900$ \\
\hline Total investment cost & $\$ 192,100$ & $\$ 214,150$ & $\$ 206,900$ \\
\hline Fuel cost & $\$ 280$ & $\$ 450$ & $\$ 500$ \\
\hline Maintenance cost & $\$ 1,240$ & $\$ 16,000$ & $\$ 1,600$ \\
\hline
\end{tabular}


Table 8 KPI analysis model output

\begin{tabular}{|c|c|c|c|}
\hline & System 1 & System 2 & System 3 \\
\hline Pressure drop & 1 & 1 & 1 \\
\hline Footprint (area of BWTS) & 1 & 0 & 1 \\
\hline Equipment price & 1 & 0 & 1 \\
\hline Annual operation cost & 1 & 0 & 1 \\
\hline Use of chemicals & 1 & 1 & 1 \\
\hline USCG standards & 1 & 1 & 1 \\
\hline Treatment time & 1 & 1 & 1 \\
\hline Installation cost & 1 & 0 & 1 \\
\hline Total investment cost & 1 & 0 & 1 \\
\hline Fuel cost & 1 & 0 & APPLICABLE \\
\hline Maintenance cost & 1 & APPLICABLE & \\
\hline System applicable? & APPLICABLE & & 1 \\
\hline
\end{tabular}

The first part of the KPI analysis identifies which BWTSs are applicable to the examined vessel. For this case, System 2 is identified as Not Applicable. In the second part of the analysis, the coefficients of the key factors are calculated and the grades for each system are indicated. Although System 2 was deemed Not Applicable in the first stage, it is included in the calculations to show how the second part works. In Table 9, the results for $n_{\min }$ are given to allow $C_{i}$ to be calculated.

Table 9 Values of $n_{\text {min }}$ for KPI analysis

\begin{tabular}{|c|c|}
\hline KPI & $\boldsymbol{n}_{\min }$ \\
\hline Pressure drop & 0.3 \\
\hline Footprint (area of BWTS) & 2.17 \\
\hline Equipment price & $\$ 185,000$ \\
\hline Annual operation cost & $\$ 1,240$ \\
\hline
\end{tabular}

The values of the coefficient $C_{i}$ are calculated using Eq. (1) with the values of $n_{i}$ given in Table 9, and are given in Table 10. The values obtained using Eq. (1) are then passed to Eq. (2). The value of $C_{G \max }$ for each category and grade are calculated in this way and are given in Table 11. 
Table 10 System values of $C_{i}$ for KPI analysis

\begin{tabular}{|c|c|c|c|}
\hline \multirow{2}{*}{ KPI } & \multicolumn{3}{|c|}{$C_{i}$} \\
\cline { 2 - 4 } & System 1 & System 2 & System 3 \\
\hline Pressure drop & 2,333 & 3,000 & 1,000 \\
\hline Footprint (area of BWTS) & 1,000 & 2,597 & 1,648 \\
\hline Equipment price & 1,000 & 1,097 & 1,081 \\
\hline Annual operation cost & 1,000 & 11,815 & 1,694 \\
\hline
\end{tabular}

Table 11 Values of $C_{G \max }$ for KPI analysis

\begin{tabular}{|c|c|c|c|c|}
\hline \multirow{2}{*}{$\boldsymbol{G}$} & \multicolumn{4}{|c|}{$\boldsymbol{C}_{\mathbf{G m a x}}$} \\
\cline { 2 - 5 } & Pressure drop & Footprint & Equipment price & $\begin{array}{c}\text { Annual } \\
\text { operation cost }\end{array}$ \\
\hline $\mathbf{1}$ & 1,333 & 1,266 & 1,016 & 2,802 \\
\hline $\mathbf{2}$ & 1,667 & 1,532 & 1,032 & 4,605 \\
\hline $\mathbf{3}$ & 2,000 & 1,798 & 1,049 & 6,407 \\
\hline $\mathbf{4}$ & 2,333 & 2,065 & 1,065 & 8,210 \\
\hline $\mathbf{5}$ & 2,667 & 2,331 & 1,081 & 10,012 \\
\hline $\mathbf{6}$ & 3,000 & 2,597 & 1,097 & 11,815 \\
\hline
\end{tabular}

By comparing the coefficients given in Tables 10 and 11, the grades of each system and each factor are identified. For example, for System 1, the $C i$ value of the pressure drop is 2,333. So, the grade is 4 because 2,333 is greater than 2,000 and equal to 2,333. This means that the grade for the pressure drop of System 1 is 4 . The grades calculated by the model are given in Table 12.

Table 12 System grades calculated by KPI

\begin{tabular}{|c|c|c|c|}
\hline \multirow{2}{*}{ KPI } & \multicolumn{3}{|c|}{ Grade } \\
\cline { 2 - 4 } & System 1 & System 2 & System 3 \\
\hline Pressure drop & 4 & 6 & 1 \\
\hline Footprint (area of BWTS) & 1 & 6 & 3 \\
\hline Equipment price & 1 & 6 & 5 \\
\hline Annual operation cost & 1 & 6 & 1 \\
\hline
\end{tabular}

System 2 was evaluated as "Not Applicable" in the first stage of analysis. As expected, all grades for each category of System 2 are 6, which is the worst grade. Table 12 show that System 1 is the most applicable BWTS for the fishing vessel. 
As mentioned previously, we consider the degree of importance of the key factors. By weighting the grades, the model calculates the average score for all KPIs. The overall scores stated in Table 13 were calculated by multiplying the average of the system grades by 10 . In this table, the highest score, which is 15 in this case, represents the worst case. The lowest score, which is 4 in this case, represents the most suitable system.

Table 13 Systems scores

\begin{tabular}{|c|c|c|c|}
\hline KPI & System 1 & System 2 & System 3 \\
\hline Pressure drop & 0,800 & 1,200 & 0,200 \\
\hline Footprint (area of BWTS) & 0,150 & 0,900 & 0,450 \\
\hline Equipment price & 0,500 & 3,000 & 2,500 \\
\hline Annual operation cost & 0,150 & 0,900 & 0,150 \\
\hline Score & 4 & 15 & 8.25 \\
\hline
\end{tabular}

\subsection{KPI-based selection of BWTS: dry bulk carrier vessel}

The technical specifications of the BWTSs considered for the dry bulk carrier are given in Table 14. In order to conduct the KPI analysis, the criteria stated in Table 15 are used in the Excel model [21]. The values for each system are given in Table 16.

Table 14 Technical specification of BWTSs considered for dry bulk carrier

\begin{tabular}{|c|c|c|c|c|}
\hline & & System 1 & System 2 & System 3 \\
\hline $\begin{array}{r}\text { Method u } \\
\text { ballas }\end{array}$ & $\begin{array}{l}\text { d to treat } \\
\text { water }\end{array}$ & Filtration + UV & Filtration + UV & Electrochemical \\
\hline & Uptake & Filtration + UV & Filtration + UV & Electrochemical \\
\hline & Discharge & UV & UV & Neutralization \\
\hline & & 40 microns & 55 microns & - \\
\hline Pressu & e drop & 0.8 bar & 0.7 bar & 0.2 bar \\
\hline UV unit & capacity & $250 \mathrm{~m}^{3} / \mathrm{h}$ & $255 \mathrm{~m}^{3} / \mathrm{h}$ & - \\
\hline Power & Usage & $18-41 \mathrm{~kW}$ & $18-25 \mathrm{~kW}$ & $27.4 \mathrm{~kW}$ \\
\hline
\end{tabular}


Table 15 KPI analysis input data

\begin{tabular}{|c|c|}
\hline KPI & Criteria \\
\hline Pressure drop & $1 \mathrm{bar}$ \\
\hline Footprint (area of BWTS) & $7 \mathrm{~m}^{2}$ \\
\hline Equipment price & $\$ 230,000$ \\
\hline Annual operation cost & $\$ 2,000$ \\
\hline Use of chemicals & No \\
\hline USCG standards & No \\
\hline Treatment time & Uptake \\
\hline Installation cost & $5 \%$ of equipment price \\
\hline Total investment cost & $\$ 241,500$ \\
\hline Fuel cost & $\$ 900$ \\
\hline Maintenance cost & $\$ 1,000$ \\
\hline
\end{tabular}

Table 16 KPI analysis system data

\begin{tabular}{|c|c|c|c|}
\hline & System 1 & System 2 & System 3 \\
\hline Pressure drop & $0.8 \mathrm{bar}$ & $0.7 \mathrm{bar}$ & $0.2 \mathrm{bar}$ \\
\hline Footprint (area of BWTS) & $6.12 \mathrm{~m}^{2}$ & $6.44 \mathrm{~m}^{2}$ & $2.48 \mathrm{~m}^{2}$ \\
\hline Equipment price & $\$ 220,000$ & $\$ 215,000$ & $\$ 188,000$ \\
\hline Annual operation cost & $\$ 1,850$ & $\$ 1,660$ & $\$ 120$ \\
\hline Use of chemicals & No & No & No \\
\hline USCG standards & No & No & No \\
\hline Treatment time & Uptake & Uptake & Uptake \\
\hline Installation cost & $\$ 1,800$ & $\$ 6,300$ & $\$ 2,000$ \\
\hline Total investment cost & $\$ 221,800$ & $\$ 221,300$ & $\$ 190,000$ \\
\hline Fuel cost & $\$ 850$ & $\$ 700$ & $\$ 120$ \\
\hline Maintenance cost & $\$ 1,000$ & $\$ 960$ & $\$ 0$ \\
\hline
\end{tabular}


The model compares the values given in Table 15 with those given in Table 16 and generates a $(1 \times 11)$ binary matrix for each system. The first part of the KPI analysis identifies which BWTSs are applicable to the examined vessel. In this case, System 3 is identified as Not Applicable (Table 17).

Table 17 KPI analysis model output

\begin{tabular}{|c|c|c|c|}
\hline & System 1 & System 2 & System 3 \\
\hline Pressure drop & 1 & 1 & 1 \\
\hline Footprint (area of BWTS) & 1 & 1 & 1 \\
\hline Equipment price & 1 & 1 & 1 \\
\hline Annual operation cost & 1 & 1 & 1 \\
\hline Use of chemicals & 1 & 1 & 1 \\
\hline USCG standards & 1 & 1 & 1 \\
\hline Treatment time & 1 & 1 & 1 \\
\hline Installation cost & 1 & 1 & 1 \\
\hline Total investment cost & 1 & APPLICABLE & APPLICABLE \\
\hline Fuel cost & APPLICABLE & APPOT & 1 \\
\hline Maintenance cost & & 1 & 1 \\
\hline System applicable? & 1 & 1 & 1 \\
\hline
\end{tabular}

In the second part, the coefficients of the key factors are calculated and the grades for each system are indicated. The results for $n_{\min }$ given in Table 18 are used to calculate $C_{i}$.

Table 18 Values of $n_{\min }$ for KPI analysis

\begin{tabular}{|c|c|}
\hline KPI & $\boldsymbol{n}_{\text {min }}$ \\
\hline Pressure drop & 0.2 \\
\hline Footprint (area of BWTS) & 2.48 \\
\hline Equipment price & 188,000 \\
\hline Annual operation cost & 120 \\
\hline
\end{tabular}

Values of the coefficient $C_{i}$ are calculated using Eq. (1) with the values of $n_{i}$ given in Table 18. The corresponding values of $C_{i}$ are given in Table 19. 
Table 19 System values of $C_{i}$ for KPI analysis

\begin{tabular}{|c|c|c|c|}
\hline \multirow{2}{*}{ KPI } & \multicolumn{3}{|c|}{$C_{\boldsymbol{i}}$} \\
\cline { 2 - 4 } & System 1 & System 2 & System 3 \\
\hline Pressure drop & 4,000 & 3,500 & 1,000 \\
\hline Footprint (area of BWTS) & 2,463 & 2,592 & 1,000 \\
\hline Equipment price & 1,170 & 1,144 & 1,000 \\
\hline Annual operation cost & 15,417 & 13,833 & 1,000 \\
\hline
\end{tabular}

The values obtained with Eq. (1) are passed to Eq. (2). The $C_{G \max }$ values for each category and grade are calculated in this way.

Table 20 Values of $C_{G \max }$ for KPI analysis

\begin{tabular}{|c|c|c|c|c|}
\hline \multirow{2}{*}{$\boldsymbol{G}$} & \multicolumn{4}{|c|}{$\boldsymbol{C}_{\boldsymbol{G m a x}}$} \\
\cline { 2 - 5 } & $\begin{array}{c}\text { Pressure } \\
\text { drop }\end{array}$ & Footprint & $\begin{array}{c}\text { Equipment } \\
\text { price }\end{array}$ & $\begin{array}{c}\text { Annual operation } \\
\text { cost }\end{array}$ \\
\hline $\mathbf{1}$ & 1,500 & 1,265 & 1,028 & 3,403 \\
\hline $\mathbf{2}$ & 2,000 & 1,531 & 1,057 & 5,806 \\
\hline $\mathbf{3}$ & 2,500 & 1,796 & 1,085 & 8,208 \\
\hline $\mathbf{4}$ & 3,000 & 2,061 & 1,113 & 10,611 \\
\hline $\mathbf{5}$ & 3,500 & 2,327 & 1,142 & 13,014 \\
\hline
\end{tabular}

By comparing the coefficients given in Tables 19 and 20, the grades of each system and each factor are identified. For example, for System 2, the $C_{i}$ value of the equipment price is 1,144 . So, the grade is 5 because 1,144 is greater than 1,142 . This means that the grade for the equipment price of System 2 is 5 . The grades calculated by the model are given in Table 21 .

Table 21 System grades calculated by KPI

\begin{tabular}{|c|c|c|c|}
\hline \multirow{2}{*}{ KPI } & \multicolumn{3}{|c|}{ Grade } \\
\cline { 2 - 4 } & System 1 & System 2 & System 3 \\
\hline Pressure drop & 6 & 5 & 1 \\
\hline Footprint (area of BWTS) & 6 & 6 & 1 \\
\hline Equipment price & 6 & 6 & 1 \\
\hline Annual operation cost & 6 & 6 & 1 \\
\hline
\end{tabular}

By weighting the grades, the model calculates the average score for all KPIs. The overall scores given in Table 22 were calculated by multiplying the average of the system grades by 
10. In this table, the highest score of 15 represents the worst case, and the lowest score of 2.5 represents the most suitable system. However, although System 3 has the best result, it was found in the first stage of the analysis not to be applicable for this specific vessel (the shipowner was reluctant to invest in a BWTS that used a chemical treatment method).

Table 22 Systems scores

\begin{tabular}{|c|c|c|c|}
\hline & System 1 & System 2 & System 3 \\
\hline Pressure drop & 1,200 & 1,000 & 0,200 \\
\hline Footprint (area of BWTS) & 0,900 & 0,900 & 0,150 \\
\hline Equipment price & 3,000 & 3,000 & 0,500 \\
\hline Annual operation cost & 0,900 & 0,900 & 0,150 \\
\hline Score & 15 & 14.5 & 2.5 \\
\hline
\end{tabular}

\section{Conclusions}

The BWM convention met its ratification criteria on September 8, 2016, having finally pushed the scales past the $35 \%$ of the world's fleet by gross tonnage following Finland's ratification. The IMO's International Convention for the Control and Management of Ships' Ballast Water and Sediments, 2004 ("the Convention") will come into force on September 8, 2017. As of January 11, 2017, there were 54 Contracting States to the Convention, representing $53.30 \%$ of the world's global tonnage [6]. As the enforcement date approaches, there is a sense of urgency among ship owners to start planning for the procurement and installation of BWTSs. The demand for such systems is going to increase, and shipyard capacity needs to increase correspondingly. Owners who have not done anything so far need to start making investments within the next few months.

The period between 2018 to 2022 is likely to be extremely busy and hectic for shipowners and BWTS manufacturers. Shipyards may have problems choosing the most suitable BWTS for each ship because they will have to decide which system to use in a very limited time. After the Convention comes into force, shipyards will face a heavy workload and a limited time. As mentioned in the Introduction, many decision-support tools are available, but KPI is one of the more practical methods for selecting a suitable BWTS for a particular ship; KPIs are well-known decision or performance-measurement tools in many areas of the shipping industry.

The aim of this study was to use a decision-support tool to help select a BWTS by considering both the technical and economic aspects of the system. It is known that criteria related to the treatment system influence decisions on BWTS selection. The use of the KPI method in selecting a BWTS for a fishing vessel and another for a dry bulk carrier was discussed in detail. The KPI approach is already known at the shipyard in Istanbul that built these particular ships. Three different types of BWTS for each of the two vessels were examined using KPI to identify the optimum one. The KPI model was implemented in Excel to evaluate the systems in detail both technically and economically. In the first part of the evaluation, the key data and the system specifications were compared, and the applicability of each system was assessed. In the second part of the model, the system criteria were graded from 1 to 6 and compared with each other. With this application, every component of the systems is evaluated in detail and the most appropriate system for the specific vessel is stated. The BWTS vendors and the purchaser companies of the vessel have been kept confidential. 
The results support Berntzen's study [15] and show that the application of KPIs for BWTS selection is a very useful way for shipyards to compare BWTSs to make better choices and to designate the most suitable system for each of their ships. The application of the KPI support tool is also easy for the end user because it is implemented in Excel.

The short literature review regarding the decision-support tools showed that both shiprelated and BWTS-related criteria influence the selection. Future development work on decision-support tools for BWTS selection for a ship will require a considerable amount of reliable data, both from ships to be fitted with BWTSs and from the manufacturers/vendors of competing BWTSs. Therefore, more elaborate analysis and investigation are required to establish the applicability and validity of all decision-support methods.

\section{Acknowledgments}

The authors gratefully acknowledge the sponsorship of the Cemre Shipyard in Istanbul, where one of the authors (MSc student) had been working as a Shipbuilding \& Ocean Engineer. This paper is based on the MSc studies completed by G. Vural under the supervision of F. Yonsel and accepted by Istanbul Technical University in December 2015.

\section{REFERENCES}

[1] Endersen, Ø et al. (2004). Challenges in Ballast Water Management. Marine Pollution Bulltein, 48, 615623. https://doi.org/10.1016/j.marpolbul.2004.01.016.

[2] Endersen Ø et al. (2003). How much ballast? Global Ballast Water Management Programme, Ballast water News, Issue 14, July-September 2003.

[3] Balaji, R., \& Yaakob, O. B. (2011). Emerging Ballast Water Treatment Technologies: A Review, Journal of Sustainability Science and Management, 6:1, 126-138.

[4] Carlton, J.T. (2001). Introduced Species in U.S. Coastal Waters: Environmental Impacts and Management Priorities. Pew Oceans Commission, Arlington VA.

[5] Tímár, L. (2008). Modeling the Anthropogenic Spread of an Aquatic Invasive Species: The Case of Zebra Mussels and Transient Recreational Boating in Wisconsin. (Doktora tezi). Graduate Faculty of North Carolina State University, North Carolina.

[6] http://www.imo.org/en/About/Conventions/StatusOfConventions/Documents/Status\%20of\%20Treaties.p df [Online]. [Accessed 12.03.2017].

[7] International Chamber of Shipping-ICS (2016). Annual Review.

[8] http://www.imo.org/en/OurWork/Environment/BallastWaterManagement/Documents/Table\%20of\%20B A\%20FA\%20TA\%20updated\%20November\%202016.pdf [Online]. [Accessed 30.01.2017].

[9] ABS. (2011) Ballast Water Treatment Advisory, TX 04/11 600011052.

[10] Perakis, A.N. \& Yang, Z. (2003). Options for nonindigenous species control and their economic impact on the Great Lakes and St. Lawrence seaway: A survey. Marine Technology, 40, 34-41.

[11] Rigby, G., Hallegraeff, G. \& Sutton, C. (1999). Novel Ballast Water Heating Technique Offers CostEffective Treatment To Reduce The Risk of Global Transport of Harmful Marine Organisms. Marine Ecology. Progress Series, 191, 289-293. https://doi.org/10.3354/meps191289.

[12] Parsons, M.G. (2003). Considerations In The Design of The Primary Treatment For Ballast Systems. Marine Technology, 40, 49-60.

[13] Gomes, C.F.S. (2005). Using MCDA Methods THOR in An Application for Outranking the BWM Options. Pesquisa Operacional, 25, 11-28. https://doi.org/10.1590/S0101-74382005000100002.

[14] Mamlook, R., Badran, O., Abu-Khader, M., Holdo, A. \& Dales, J. (2008) Fuzzy Sets Analysis for BWTS: Best Available Control Technology. Clean Technologies and Environmental Policy, 10, 397-407. https://doi.org/10.1007/s10098-007-0130-7.

[15] Berntzen, M. (2010). Guidelines for Selection Of A Ship BWTS. MSc, Norwegian University of Science and Technology. 
[16] Al Hababi, Hani H M H. (2015) Development of Decision Support Tool for Advising on Selecting Ballast Water Treatment System. PhD, University of Strathclyde.

[17] Konsta, K \& Plomaritou, E. (2012) Key Performance Indicators (KPIs) and Shipping Companies Performance Evaluation: The Case of Greek Tanker Shipping Companies, International Journal of Business and Management, 7;10, 142-155. https://doi.org/10.5539/ijbm.v7n10p142.

[18] MARINTEK. (2010) The Shipping KPI Standard V2.0, December $1^{\text {st }}$.

[19] IMO, (2004). International Convention for the Control and Management of Ships' Ballast Water and Sediments, International Maritime Organization, London, UK, 14 February.

[20] David, M., Gollasch, S. \& Hewitt, C. (2014). Global Maritime Transport and Ballast Water Management, Springer, ISBN: 978-94-017-9367.

[21] Vural, G. (2015, December) Balast Suyu Arıtım Sistemlerinin Seçiminde KPI uygulamaları (KPI Applications on BWTSs selections), MSc Thesis, (in Turkish) (Supervisor: F. Yonsel), Istanbul Technical University.

Submitted: $\quad 27.10 .2016$

Accepted: 24.03.2017.
Fatma Yonsel, fyonsel@itu.edu.tr

Gülçin Vural

Istanbul Technical University, Faculty of Naval Architecture and Ocean Engineering, Department of Shipbuilding and Ocean Engineering, Maslak, 34469 Istanbul/Turkey 